\title{
Feeding diets varying in forage proportion and particle length to lactating dairy cows: I. Effects on ruminal pH and fermentation, microbial protein synthesis, digestibility, and milk production
}

\author{
Chun $\mathrm{Li}^{1}{ }^{1} \odot$ Karen A. Beauchemin, ${ }^{2} \odot$ and Wenzhu Yang ${ }^{2 *} \odot$ \\ ${ }^{1}$ College of Animal Science and Technology, Inner Mongolia University for the Nationalities, Tongliao, Inner Mongolia, China 028000 \\ ${ }^{2}$ Agriculture and Agri-Food Canada, Lethbridge Research and Development Centre, Lethbridge, AB, T1J 4B1, Canada
}

\begin{abstract}
Physically effective neutral detergent fiber (peNDF) content of dairy cow diets was modified by varying the theoretical chop length of alfalfa silage and forage: concentrate $(\mathrm{F}: \mathrm{C})$ ratio, and effects on nutrient intakes, ruminal fermentation, site and extent of digestion, microbial protein synthesis, and milk production were evaluated. Estimates of dietary peNDF contents were compared with recommendations, and predictions of ruminal $\mathrm{pH}$ from peNDF and the recently developed physically adjusted neutral detergent fiber (paNDF) system were compared with observed $\mathrm{pH}$. The experiment was designed as a triple $4 \times 4$ Latin square using 12 mid-lactating dairy cows with 4 intact, 4 ruminally cannulated, and 4 ruminally and duodenally cannulated cows. Site and extent of digestion and microbial protein synthesis were measured in a single $4 \times 4$ Latin square. Treatments were a $2 \times 2$ factorial arrangement; 2 forage particle lengths (FPL) of alfalfa silage (short and long) were combined with low (35:65) and high (60:40) F:C ratios [dry matter (DM) basis]. The peNDF contents were determined by multiplying the proportion (DM basis) of total mixed ration retained on 2 ( 8 and $19 \mathrm{~mm}$; $\left.\operatorname{peNDF}_{8.0}\right)$ or $3(1.18,8$, and $19 \mathrm{~mm}$; peNDF 1.18$)$ sieves of the Penn State Particle Separator by the neutral detergent fiber content of the diet. The dietary peNDF contents ranged from 10.7 to $17.5 \%$ for peNDF $_{8.0}$ or from 23.1 to $28.2 \%$ for peNDF 1.18 . Interactions between $\mathrm{F}: \mathrm{C}$ ratio and FPL content were few. Increasing peNDF content of diets by increasing $\mathrm{F}$ : $\mathrm{C}$ ratio decreased DM intake, milk yield, and milk protein yield, whereas apparent total-tract DM digestibility and milk efficiency improved. Increasing $\mathrm{F}: \mathrm{C}$ ratio improved ruminal $\mathrm{pH}$ status but decreased total volatile fatty acid concentration and microbial protein synthesis. Increasing peNDF
\end{abstract}

Received September 18, 2019.

Accepted December 20, 2019

*Corresponding author: wenzhu.yang@canada.ca content of diets via dietary FPL increased mean ruminal $\mathrm{pH}$, but did not affect DM intake, total-tract digestibility, or milk production. The results indicate that feeding dairy cows a low F:C diet helps increase DM intake, milk production, and microbial protein synthesis, but may adversely affect feed digestibility and milk efficiency due to increased risk of subacute ruminal acidosis. Increased FPL improved ruminal $\mathrm{pH}$ status, but had minimal effects on feed intake, ruminal fermentation, nutrient digestibility, and milk production. The results indicate a trade-off between reducing the risk of subacute ruminal acidosis and maximizing ruminal fermentation, feed digestibility, and milk production of dairy cows. The paNDF model showed improvement in the predictability of ruminal $\mathrm{pH}$ over the peNDF model, but the accuracy of predictions varied depending upon the diet and ruminal fermentation variables considered in the equations.

Key words: alfalfa silage, physically effective fiber, digestion, dairy cow

\section{INTRODUCTION}

The incidence of SARA is a tremendous problem for the dairy industry, causing losses in production efficiency and increased costs of treating sick animals (Zebeli et al., 2012). Adequate forage NDF content and particle length of dairy cow diets helps prevent the occurrence of SARA and promotes healthy ruminal function. The concept of physically effective NDF (peNDF) was developed to reflect the ability of physical characteristics of fiber to stimulate chewing and salivary buffering of the rumen, thereby improving ruminal $\mathrm{pH}$ status and maintaining a rumen digesta mat (Mertens, 1997). A laboratory method based on a dry sieving technique with vigorous vertical shaking was proposed by Mertens (1997) to determine peNDF of a feed, expressed as the proportion of DM retained on a $1.18-\mathrm{mm}$ sieve multiplied by its dietary NDF content. Lammers et al. (1996) developed the Penn State 
Particle Separator (PSPS) with horizontal sieving for routine on-farm measurement of particle length of feeds. Since then, the PSPS system has been widely adopted for use on the farm, with the peNDF content of a diet determined by multiplying the proportion of particles retained on various sieves of the PSPS by dietary NDF content. The proportions retained on the 19- and 8-mm sieve are used to calculate $\mathbf{p e N D F}_{\mathbf{8 . 0}}$, whereas the proportions retained on the 19-, 8-, and 1.18-mm sieves are used to determine $\mathbf{p e N D F}_{1.18}$ (Kononoff et al., 2003). A particle length of $1.18 \mathrm{~mm}$ was used in these early studies because it was considered to be a threshold that increases the resistance of particles to leaving the rumen in cattle and sheep. However, others have questioned that threshold (Maulfair et al., 2011), and hence a $4-\mathrm{mm}$ sieve was added to the PSPS to quantify the proportion of small forage particles that are often high in fiber (Heinrichs, 2013).

Several studies have examined the concept of peNDF over the past decades as summarized by Zebeli et al. (2012) and White et al. (2017a). Observed over a large number of studies, increased intake of peNDF is associated with an increase in chewing activity and ruminal pH (Yang and Beauchemin, 2009; Wang et al., 2017), greater milk fat content (Woolpert et al., 2017), and greater milk protein content (Caccamo et al., 2014). However, use of the peNDF concept to determine dietary fiber adequacy and predict ruminal $\mathrm{pH}$ and milk fat concentration is fraught with limitations, especially when diets are highly fermentable (White et al., 2017a). Given the numerous animal and dietary factors that affect ruminal $\mathrm{pH}$, the peNDF concept can be an oversimplification of a complex phenomenon. The peNDF content of a diet is mainly due to forage-to-concentrate ratio (F:C), forage particle length (FPL), and their interactions. A better understanding of the relative effect of these factors on peNDF intake, ruminal $\mathrm{pH}$, and digestive function of the dairy cow is needed.

White et al. (2017a) suggested that the utility of the peNDF concept could be expanded and improved upon by dissociating dietary NDF content and particle length, and by considering additional dietary factors such as diet fermentability. These researchers proposed the concept of physically adjusted NDF (paNDF) and developed models that include the key individual dietary factors that potentially affect ruminal fermentation. The models predict chewing time and ruminal $\mathrm{pH}$ and can be used to recommend minimum amounts of forage NDF needed in TMR varying in particle length, measured using the 8- and $19-\mathrm{mm}$ sieves of the PSPS (White et al., 2017b). Thus the paNDF system does not directly combine particle length and NDF measurements as is done in the peNDF system; however, these
2 physical fiber concepts have not yet been compared using an independent data set.

We hypothesized that (1) altering dietary peNDF content by manipulating $\mathrm{F}: \mathrm{C}$ ratio and FPL would affect feed degradation in the rumen, digestibility in the total digestive tract, and thus the productivity of dairy cattle; and (2) use of the paNDF concept would improve the predictability of ruminal $\mathrm{pH}$ compared with peNDF. The objectives of this study were to determine the effects of altering $\mathrm{F}: \mathrm{C}$ ratio of the diet and FPL of alfalfa silage (AS), as a means of altering peNDF intake of lactating dairy cows, on feed intake, ruminal $\mathrm{pH}$ and fermentation, site and extent of digestion, microbial protein synthesis, and milk yield and composition. The data for ruminal $\mathrm{pH}$ were compared with predictions of ruminal $\mathrm{pH}$ using peNDF and paNDF. A sole forage was used in the study to eliminate potential interactions among forage sources. Alfalfa silage was used in the study to minimize the intake of starch from forage sources. Furthermore, AS is widely used in dairy cow diets in North America (Lopes et al., 2015). It has greater CP and NPN (NRC, 2001) and greater rate of NDF digestion compared with corn silage (Herrick et al., 2012; Lopes et al., 2015).

\section{MATERIALS AND METHODS}

\section{Alfalfa Silage}

Second-cut, wilted alfalfa was harvested at the early bloom stage of maturity and ensiled in large silo bags (200 t capacity) for 2 mo before being used. A forage harvester (model 6910, John Deere, West Bend, WI), equipped with a 37-tooth sprocket and 8 knives, was used to obtain silage chopped at a theoretical chop length of 7.9 and $19.1 \mathrm{~mm}$ for short- and long-cut silage, respectively. Alfalfa silages were sampled weekly during the study to determine particle length distribution and chemical composition.

\section{Cows and Diets}

Twelve mid-lactation dairy cows (mean \pm SD: 644 $\pm 47 \mathrm{~kg}$ of average BW; $135 \pm 25$ DIM) including 4 intact, 4 ruminally cannulated, and 4 ruminally and duodenally cannulated cows, were used and cared for according to the guidelines of the Canadian Council on Animal Care (2009). The experiment was designed as multiple $4 \times 4$ Latin squares with a $2 \times 2$ factorial arrangement of treatments for measuring feed intake, total-tract nutrient digestibility, milk yield, and milk composition. Total-tract nutrient digestibility and milk variables were measured in 3 squares $(\mathrm{n}=12$ cows/ 
treatment); ruminal $\mathrm{pH}$ and fermentation parameters were measured in 2 squares $(\mathrm{n}=8$ cows/treatment); and site and extent of digestibility in the rumen and in the intestine, and ruminal microbial protein production were measured in 1 square ( $\mathrm{n}=4$ cows/treatment). The ruminal cannulas measured $10 \mathrm{~cm}$ in diameter and were constructed of soft plastic (Bar Diamond, Parma, ID). Duodenal cannulas were T-shaped and were placed proximal to the common bile and pancreatic duct, approximately $10 \mathrm{~cm}$ distal to the pylorus. Cows were housed in individual tiestalls and offered a TMR 3 times daily at 0600, 1500, and $1800 \mathrm{~h}$ for ad libitum intake.

Cows were offered 1 of 4 experimental diets that consisted of short and long AS, combined with low (35:65) and high (60:40) F:C ratio (DM basis; Table 1 ). Thus, concentration of dietary peNDF was increased by increasing FPL and proportion of forage in the diet (Table 2). The diets were formulated using the NRC model (NRC, 2001) to supply sufficient energy and protein for a $650-\mathrm{kg}$ cow to produce $35 \mathrm{~kg} / \mathrm{d}$ of milk containing $3.5 \%$ fat and $3.2 \%$ protein.
Each period consisted of $14 \mathrm{~d}$ of adaptation to diets and $7 \mathrm{~d}$ of experimental measurements. Feed offered and orts were measured and recorded daily during the last $7 \mathrm{~d}$ of the period to calculate DMI. Samples of AS and TMR were collected once weekly, and orts were collected daily and composited weekly for particle length and DM determination. Samples were composited by period, dried in an oven at $55^{\circ} \mathrm{C}$ for $48 \mathrm{~h}$, and then ground through a 1-mm screen (standard model 4, Arthur Thomas Co., Philadelphia, PA) for analysis of $\mathrm{OM}, \mathrm{NDF}, \mathrm{ADF}$, starch, and CP. Milk production was recorded daily, a.m. and p.m., and sampled on 5 consecutive days during the last $7 \mathrm{~d}$ of the period for milk fat, $\mathrm{CP}$, and lactose determination using an infrared analyzer (Milk-O-Scan 605, Foss Electric, Hillerød, Denmark).

\section{Ruminal $\mathrm{pH}$ and Fermentation}

Ruminal $\mathrm{pH}$ was continuously monitored for $48 \mathrm{~h}$ starting on d 15 using the Lethbridge Research Centre Ruminal pH Measurement System (LRCpH, Dascor,

Table 1. Ingredients of the total mixed diet (DM basis)

\begin{tabular}{|c|c|c|c|c|}
\hline \multirow[b]{3}{*}{ Ingredient, \% } & \multicolumn{4}{|c|}{$\mathrm{F}: \mathrm{C}^{1}$} \\
\hline & \multicolumn{2}{|c|}{$35: 65$} & \multicolumn{2}{|c|}{$60: 40$} \\
\hline & Short & Long & Short & Long \\
\hline Alfalfa silage, short cut & 35.5 & - & 59.7 & - \\
\hline Alfalfa silage, long cut & - & 35.5 & - & 59.7 \\
\hline Corn grain, dry-rolled ${ }^{2}$ & 40.4 & 40.4 & 26.8 & 26.8 \\
\hline \multicolumn{5}{|l|}{ Pelleted supplement } \\
\hline Corn gluten meal & 1.11 & 1.11 & 3.57 & 3.57 \\
\hline High RUP canola meal (Alberta Gold) ${ }^{3}$ & 3.10 & 3.10 & 1.11 & 1.11 \\
\hline Soybean meal & 5.32 & 5.32 & - & - \\
\hline High RUP soybean meal (Soypass) ${ }^{4}$ & - & - & 1.11 & 1.11 \\
\hline Beet molasses & 0.89 & 0.89 & 0.58 & 0.58 \\
\hline Beet sugar pulp & 11.53 & 11.53 & 4.46 & 4.46 \\
\hline Urea & 0.27 & 0.27 & - & - \\
\hline Calcium carbonate & 0.27 & 0.27 & 0.18 & 0.18 \\
\hline Dicalcium phosphorus & 0.27 & 0.27 & 0.31 & 0.31 \\
\hline Monosodium phosphate & 0.09 & 0.09 & 0.13 & 0.13 \\
\hline Vitamin-mineral mix $^{5}$ & 0.67 & 0.67 & 0.67 & 0.67 \\
\hline Canola oil & 0.40 & 0.40 & 0.27 & 0.27 \\
\hline Ca salts of long-chain fatty acids (Enertia) $)^{6}$ & - & - & 0.98 & 0.98 \\
\hline Binding agent $(\mathrm{Aka})^{7}$ & 0.27 & 0.27 & 0.13 & 0.13 \\
\hline \multicolumn{5}{|c|}{$\begin{array}{l}{ }^{1} \text { Alfalfa forage was harvested at a theoretical chop length of } 19.1 \text { or } 7.9 \mathrm{~mm} \text { for long- and short-cut silages, } \\
\text { respectively. Diets were formulated using the NRC model (NRC, 2001). }\end{array}$} \\
\hline \multirow{2}{*}{\multicolumn{5}{|c|}{$\begin{array}{l}{ }^{2} \mathrm{Chemical} \text { composition of corn grain (DM basis) was } 98.0 \% \mathrm{OM}, 12.8 \% \mathrm{NDF}, 3.8 \% \mathrm{ADF}, 70.6 \% \text { starch, and } \\
9.34 \% \mathrm{CP} \text {. } \\
{ }^{3} \mathrm{~A} \text { registered trademark for heat-processed canola meal product (Canbra Foods, Lethbridge, AB, Canada). } \\
{ }^{4} \text { Cargill (Des Moines, IA). }\end{array}$}} \\
\hline & & & & \\
\hline \multicolumn{5}{|c|}{$\begin{array}{l}{ }^{5} \text { Contained } 58.8 \% \mathrm{NaCl}, 16.0 \% \text { Dynamate (Pitman Moore Inc., Mundelein, IL; } 18 \% \mathrm{~K}, 11 \% \mathrm{Mg}, 22 \% \mathrm{~S}, 1,000 \\
\mathrm{mg} \text { of } \mathrm{Fe} / \mathrm{kg} \text { ), } 2 \% \mathrm{ZnSO}_{4} \cdot \mathrm{H}_{2} \mathrm{O}, 2.4 \% \mathrm{MnSO}_{4} \cdot 4 \mathrm{H}_{2} \mathrm{O}, 0.01 \% \mathrm{CoSO}_{4} \cdot 6 \mathrm{H}_{2} \mathrm{O}, 0.009 \% \mathrm{Na}_{2} \mathrm{SeO}_{3}, 0.012 \% \text { ethylenedi- } \\
\text { amine dihydroiodide, } 0.8 \% \mathrm{CuSO}_{4} \cdot 5 \mathrm{H}_{2} \mathrm{O}, 2,000,000 \mathrm{IU} \text { of vitamin } \mathrm{A} / \mathrm{kg}, 200,000 \mathrm{IU} \text { of vitamin D } / \mathrm{kg} \text {, and } 2,000 \\
\text { IU of vitamin E } / \mathrm{kg} \text {. }\end{array}$} \\
\hline${ }^{6} \mathrm{ADM}$ Animal Health and Nutrition (Quincy & & & & \\
\hline
\end{tabular}


Table 2. Physical and chemical composition of alfalfa silage and experimental diets ${ }^{1}$

\begin{tabular}{|c|c|c|c|c|c|c|}
\hline \multirow[b]{3}{*}{ Item } & & & \multicolumn{4}{|c|}{$\mathrm{F}: \mathrm{C}$} \\
\hline & \multicolumn{2}{|c|}{ Alfalfa silage $^{2}$} & \multicolumn{2}{|c|}{$35: 65$} & \multicolumn{2}{|c|}{$60: 40$} \\
\hline & Short & Long & Short & Long & Short & Long \\
\hline \multicolumn{7}{|l|}{ Physical $^{3}$} \\
\hline $19.0 \mathrm{~mm}$ & 15.6 & 27.1 & 4.4 & 6.8 & 8.3 & 11.6 \\
\hline $8.0 \mathrm{~mm}$ & 37.5 & 47.9 & 34.9 & 43.9 & 33.9 & 44.0 \\
\hline $1.18 \mathrm{~mm}$ & 40.1 & 21.6 & 44.5 & 35.7 & 44.5 & 33.5 \\
\hline Pan & 6.8 & 3.4 & 18.3 & 12.6 & 14.6 & 10.2 \\
\hline $\operatorname{pef}_{8.0}$ & 53.1 & 75.1 & 39.1 & 50.4 & 42.1 & 55.3 \\
\hline pef $_{1.18}$ & 93.2 & 96.6 & 83.7 & 86.3 & 86.8 & 89.0 \\
\hline $\operatorname{peNDF}_{8.0}, \%$ & 23.8 & 34.1 & 10.8 & 14.2 & 13.5 & 17.6 \\
\hline $\operatorname{peNDF}_{1.18}, \%$ & 41.9 & 43.9 & 23.1 & 24.3 & 27.8 & 28.2 \\
\hline MPL, mm & 7.31 & 9.69 & 5.55 & 6.72 & 5.91 & 7.27 \\
\hline $\mathrm{SD}$ of MPL, mm & 2.04 & 2.33 & 2.89 & 2.76 & 2.72 & 2.60 \\
\hline \multicolumn{7}{|l|}{ Chemical composition } \\
\hline $\mathrm{DM}, \%$ & 54.6 & 51.9 & 75.7 & 71.1 & 69.6 & 66.8 \\
\hline $\mathrm{OM}, \%$ of $\mathrm{DM}$ & 89.1 & 88.9 & 92.1 & 92.5 & 91.1 & 91.0 \\
\hline $\mathrm{CP}, \%$ of DM & 21.1 & 21.0 & 19.9 & 19.7 & 19.7 & 20.1 \\
\hline $\mathrm{ADF}, \%$ of $\mathrm{DM}$ & 36.6 & 37.4 & 19.5 & 19.4 & 24.2 & 24.8 \\
\hline NDF, \% of DM & 44.9 & 45.4 & 27.7 & 28.7 & 32.0 & 31.8 \\
\hline Forage NDF, $\%$ of DM & - & - & 15.7 & 15.9 & 26.9 & 27.2 \\
\hline$\%$ NDF from forage & - & - & 56.7 & 55.4 & 84.2 & 85.7 \\
\hline Starch, \% of DM & - & - & 31.9 & 31.9 & 21.7 & 21.7 \\
\hline Ether extract, $\%$ of DM & 2.48 & 2.48 & 3.38 & 3.38 & 3.97 & 3.97 \\
\hline $\mathrm{NE}_{\mathrm{L}}, \mathrm{Mcal} / \mathrm{kg}$ & - & - & 1.62 & 1.62 & 1.61 & 1.61 \\
\hline
\end{tabular}

${ }^{1}$ Means of 4 composited samples from 4 experimental periods.

${ }^{2}$ Alfalfa forage was harvested at a theoretical chop length of 19.1 and $7.9 \mathrm{~mm}$ for long- and short-cut silages, respectively.

${ }^{3}$ Particle length distribution of alfalfa silage and TMR was measured using the Penn State Particle Separator (Kononoff et al., 2003); pef $f_{8.0}$ and pef f.18 $_{18}=$ physical effectiveness factor determined as the proportion of particles retained on 2 sieves (Lammers et al., 1996) and 3 sieves (Kononoff et al., 2003), respectively; peNDF ${ }_{8.0}$ and peNDF $_{1.18}=$ physically effective NDF determined as NDF content of TMR multiplied by pef $f_{8.0}$ and pef $_{1.18}$, respectively; MPL = mean particle length, estimated as $50 \%$ of the particles greater or less than this length.

Escondido, CA). Ruminal $\mathrm{pH}$ readings were taken every $30 \mathrm{~s}$ and stored by the data logger (model M1b$\mathrm{pH}-1 \mathrm{KRTD}$, Dascor). Ruminal $\mathrm{pH}$ data were summarized daily as mean, minimum, and maximum $\mathrm{pH}$, area between the observed $\mathrm{pH}$ and a line drawn at $\mathrm{pH} 5.8$ or 5.5, and time (h) under $\mathrm{pH} 5.8$ or 5.5. Ruminal fluid was collected on d 15 and 16 at 0900, 1300, 1600, and $2000 \mathrm{~h}$ from multiple sites (dorsal, ventral, and blind sacs) in the rumen for VFA and $\mathrm{NH}_{3}-\mathrm{N}$ determination. Samples were immediately squeezed through a nylon mesh (1 mm pore size) and subsamples $(5 \mathrm{~mL})$ of filtrate were preserved with $1 \mathrm{~mL}$ of $25 \%$ (wt/vol) $\mathrm{HPO}_{3}$ and $1 \mathrm{~mL}$ of $1 \% \mathrm{H}_{2} \mathrm{SO}_{4}$ for later determination of VFA and $\mathrm{NH}_{3}-\mathrm{N}$ concentrations, respectively.

\section{Duodenal Flow and Apparent Digestibility}

Apparent digestibility of nutrients in the total digestive tract (12 cows) and duodenal flow and digestibility at the different sites of the digestive tract (4 duodenally cannulated cows) were determined using $\mathrm{YbCl}_{3}$ (Rhône-Poulenc Inc., Shelton, CT) as an exter- nal digestive marker. Ytterbium product was mixed into the concentrate portion of the diets to achieve intake of approximately $1.5 \mathrm{~g}$ of $\mathrm{Yb} / \mathrm{cow}$ per day. ${ }^{15} \mathrm{~N}$ labeled ammonium sulfite $\left(10.6 \%\right.$ atom $\%{ }^{15} \mathrm{~N}$; Isotec, Miamisburg, $\mathrm{OH}$ ) was used as ruminal microbial marker. Marker solution containing ammonia ${ }^{15} \mathrm{~N}$ was continuously infused into the rumen of the 4 duodenal cannulated cows via their ruminal cannulas using an automatic pump (model $60 \mathrm{RPM} / 7524-10$, Masterflex L/S Microprocessor pump drive, Vernon Hills, IL) $7 \mathrm{~d}$ before and during the sample collection period. Daily amounts infused were $140 \mathrm{mg}$ of ${ }^{15} \mathrm{~N}$ dissolved in 800 $\mathrm{mL}$ of water for each cow. One ruminal sample was collected from each duodenally cannulated cow daily for $4 \mathrm{~d}$ during the collection period, pooled, and differentially centrifuged to obtain a ruminal bacteria pellet as described by Yang and Beauchemin (2007a). Duodenal samples were collected 4 times daily every $6 \mathrm{~h}$ moving ahead $2 \mathrm{~h}$ each day for the last $4 \mathrm{~d}$ of infusion. Fecal samples ( 200 g of wet weight) were collected from the rectum of each cow twice daily every $12 \mathrm{~h}$ moving ahead $2 \mathrm{~h}$ each day for the last $6 \mathrm{~d}$ of the period. This 
schedule provided twelve 2-h samples of duodenal and fecal contents. Each duodenal sample was split into 3 fractions that were pooled by cow within period and retained for $\mathrm{NH}_{3}-\mathrm{N}$ analysis, DM determination after oven-drying at $55^{\circ} \mathrm{C}$, or chemical analysis after freezedrying. Fecal samples were immediately subsampled (about $50 \mathrm{~g}$ wet), composited across sampling times for each cow and each period, dried at $55^{\circ} \mathrm{C}$, ground to pass a 1-mm sieve (standard model 4, Arthur Thomas Co., Philadelphia, PA), and stored for chemical analysis.

\section{Chemical and Physical Analyses}

Feed DM was determined by oven-drying at $55^{\circ} \mathrm{C}$ for $48 \mathrm{~h}$. Analytical DM was determined by drying at $135^{\circ} \mathrm{C}$ for $2 \mathrm{~h}$, followed by hot weighing (AOAC International, 2005; method 930.05). The OM content was calculated as the difference between 100 and the percentage ash (AOAC International, 2005; method 942.05). The NDF was determined as described by Van Soest et al. (1991) using heat-stable $\alpha$-amylase (Termamyl 120L, Novo Nordisk Biochem, Franklinton, NC) and sodium sulfite, and $\mathrm{ADF}$ was determined according to AOAC International (2005; method 973.18). Starch was determined by enzymatic hydrolysis of $\alpha$-linked glucose polymers (Rode et al., 1999). Total lipids in feed samples were extracted with ethyl ether (AOAC International, 2005, method 960.39) using a Goldfisch apparatus (Laboratory Construction Co., Kansas City, MO). Contents of $\mathrm{Yb}$ in the duodenal and fecal samples were determined using inductively coupled plasma optical emission spectroscopy according to the AOAC method (AOAC International, 2005; method 968.08) modified such that no $\mathrm{CaCl}_{2}$ was used during sample digestion. Content of $\mathrm{N}$ in the samples was determined by flash combustion (model 1500, Carlo Erba Instruments, Milan, Italy) and enrichment of ${ }^{15} \mathrm{~N}$ in the rumen bacterial and duodenal samples was analyzed with isotope ratio mass spectrometry (VG Isotech, Middlewich, UK). Ruminal VFA were separated and quantified by GC (Varian 3700, Varian Specialties Ltd., Brockville, ON, Canada) using a 15-m (0.53-mm i.d.) fused silica column (DB-FFAP column, J and W Scientific, Folsom, CA). Ammonia N concentration of ruminal and duodenal samples was determined using the method described by Weatherburn (1967) modified to use a plate reader.

Particle length distributions of AS and TMR were determined using the PSPS. Physical effectiveness factors (pef) for silage and TMR were calculated as the proportion of DM retained on 2 sieves: 19 and $8 \mathrm{~mm}$ ( pef $_{8.0}$; Lammers et al., 1996) or on 3 sieves: 19, 8, and $1.18 \mathrm{~mm}$ ( pef $_{1.18}$; Kononoff et al., 2003). The peNDF contents of AS and TMR were calculated by multiplying their NDF contents by the pef ${ }_{8.0}\left(\operatorname{peNDF}_{8.0}\right)$ or pef $_{1.18}\left(\right.$ peNDF $\left._{1.18}\right)$. Both expressions of peNDF (i.e., $\operatorname{peNDF}_{8.0}$ and $\left.\mathrm{peNDF}_{1.18}\right)$ were included in the analysis to allow comparisons with previously published recommendations (Zebeli et al., 2010). Mean particle length of AS and TMR was calculated as the particle length for which $50 \%$ of the cumulative percentage weight of the sample was retained (ASAE, 1995).

\section{Calculations and Statistical Analyses}

Flows of DM to the duodenum and DM excreted in feces were calculated by dividing $\mathrm{Yb}$ actually consumed (i.e., after adjustment for $\mathrm{Yb}$ concentration of orts, grams of $\mathrm{Yb}$ per day) by $\mathrm{Yb}$ concentration (grams of $\mathrm{Yb}$ per kilogram of $\mathrm{DM}$ ) in the duodenal digesta or feces, respectively. Flows of other nutrients to the duodenum or feces were calculated by multiplying DM flow by their concentration in duodenal or fecal DM. Ruminal microbial protein synthesis for each cow was estimated by the ratio of ${ }^{15} \mathrm{~N}$ flow at the duodenum to ${ }^{15} \mathrm{~N}$ concentration of mixed ruminal bacteria. Mean ruminal $\mathrm{pH}$ was predicted using equations developed by White et al. (2017a) for peNDF and paNDF concepts by accounting for dietary variables alone or together with ruminal variables.

Data of feed intake, total-tract digestibility, and milk yield and composition were analyzed using the Mixed procedure of SAS (SAS Institute Inc., Cary, NC) to account for fixed effects of treatment (F:C and FPL) and the interaction between $\mathrm{F}: \mathrm{C}$ and FPL, and random effects of square, period within square, and cow within square. For variables of site of digestion and microbial protein synthesis, data from a single square were analyzed. In that case, the mixed model accounted for effects of period, cow, and treatment with treatment considered a fixed effect and period and cow considered random effects. The estimation method was the restrictive maximum likelihood and the degrees of freedom method was Kenward-Roger. Similarly, data for ruminal $\mathrm{pH}$, VFA, and $\mathrm{NH}_{3}-\mathrm{N}$ were analyzed by day or sampling time using repeated measures techniques. Effects of the treatments were declared significant at $P \leq$ 0.05 unless otherwise noted, and trends were discussed at $P \leq 0.10$.

\section{RESULTS}

\section{Feed peNDF Content, Intake, and Total-Tract Digestibility}

Although it was not possible to perform a statistical analysis of particle length distribution and nutrient content of AS due to the use of a single source of forage, the proportion of particles retained on 8- and 19-mm 
sieves was notably greater, whereas the proportion retained on the 1.18-mm sieve was less, for long versus short chopped AS (Table 2). As a result, the values of pef $_{8.0}$ and peNDF $_{8.0}$ were greater for long chopped AS, as expected. However, differences in pef $_{1.18}$, peNDF $_{1.18}$, and nutrient content were minimal between long and short chopped AS. The particle length distribution and peNDF content of the diets followed a pattern similar to that of the long and short chopped AS. However, increased inclusion rate of AS in the diets (i.e., increased $\mathrm{F}: \mathrm{C})$ did not alter the proportion of particles retained on 8- and 1.18-mm sieves, although the particles retained on the 19-mm sieve increased, as did pef and peNDF contents (8 and 1.18).

No interaction was observed between F:C and FPL on intakes of DM and other nutrients (Table 3). Intakes $(\mathrm{kg} / \mathrm{d})$ of DM, OM, starch, and $\mathrm{CP}$ decreased $(P<$ $0.01)$, whereas the intake of ADF increased $(P<0.01)$ without a difference in the intake of NDF, peNDF 8.0 , and peNDF $_{1.18}$ with increasing ratio of $\mathrm{F}: \mathrm{C}$ from 35:65 to 60:40. Cows fed high versus low F:C diets had greater $(P<0.01)$ intake of particles on the $19-\mathrm{mm}$ sieve, but lower intakes of particles on the $8-\mathrm{mm}(P=0.04)$ and $1.18-\mathrm{mm}(P<0.01)$ sieves. As a result, intakes of peNDF $_{8.0}$ and peNDF $_{1.18}$ were not affected by $\mathrm{F}: \mathrm{C}$ ratio. Effect of FPL on intakes of DM and other nutrients was not significant, whereas intakes of particles on the 19- and 8-mm sieves and peNDF ${ }_{8.0}$ were greater $(P<$ 0.01 ), whereas intake of particles on the $1.18-\mathrm{mm}$ sieve was less $(P<0.01)$ for long versus short AS diets.

Digestibilities of DM and other nutrients in the total digestive tract were greater $(P<0.01)$ in cows fed high F:C compared with those fed low F:C diets (Table 3). The improvement of digestibility was greatest for NDF $(+26 \%)$ and $\mathrm{ADF}(+35 \%)$, lowest for starch $(+4 \%)$, and intermediate for $\mathrm{CP}(+12 \%)$. However, altering the FPL of AS in the diets did not affect the digestibility of DM and other nutrients except that the digestibility of $\mathrm{CP}$ tended $(P=0.08)$ to be less with long versus short FPL. No interaction was observed between F:C and FPL on the digestibility of nutrients in the total digestive tract.

\section{Site and Extent of Digestion}

Intakes of DM (average, $20.7 \mathrm{~kg} / \mathrm{d}$ ) for the ruminally and duodenally cannulated cows were lower than for the average $(23.7 \mathrm{~kg} / \mathrm{d})$ of all cows because they were smaller in frame size (average BW = $613 \mathrm{~kg}$; Table 4). Similar to the observation for all cows, intake of nutrients decreased $(P<0.01)$ with increasing dietary $\mathrm{F}$ :C ratio but it was not affected by FPL. A tendency for an

Table 3. Effects of forage-to-concentrate ratio (F:C) and forage particle length (FPL) on intake and apparent total-tract digestibility of nutrients of lactating dairy cows $(\mathrm{n}=12)$

\begin{tabular}{|c|c|c|c|c|c|c|c|c|}
\hline \multirow[b]{3}{*}{ Item } & \multicolumn{4}{|c|}{$\mathrm{F}: \mathrm{C}$} & \multirow[b]{3}{*}{$\mathrm{SE}$} & \multirow{2}{*}{\multicolumn{3}{|c|}{$P$-value }} \\
\hline & \multicolumn{2}{|c|}{$35: 65$} & \multicolumn{2}{|c|}{$60: 40$} & & & & \\
\hline & Short & Long & Short & Long & & $\mathrm{F}: \mathrm{C}$ & FPL & $\mathrm{F}: \mathrm{C} \times \mathrm{FPL}$ \\
\hline \multicolumn{9}{|l|}{ Intake, $\mathrm{kg} / \mathrm{d}$} \\
\hline $\mathrm{DM}$ & 25.0 & 24.7 & 22.8 & 22.1 & 1.99 & $<0.01$ & 0.26 & 0.23 \\
\hline $\mathrm{OM}$ & 23.0 & 22.8 & 20.9 & 20.0 & 1.81 & $<0.01$ & 0.19 & 0.52 \\
\hline $\mathrm{NDF}$ & 6.8 & 7.0 & 7.0 & 6.9 & 0.64 & 0.89 & 0.99 & 0.41 \\
\hline $\mathrm{ADF}$ & 4.8 & 4.8 & 5.2 & 5.3 & 0.50 & $<0.01$ & 0.67 & 0.32 \\
\hline Starch & 8.0 & 7.8 & 4.8 & 4.7 & 0.56 & $<0.01$ & 0.25 & 0.94 \\
\hline \multirow{2}{*}{\multicolumn{9}{|c|}{ DM retained on sieves }} \\
\hline & & & & & & & & \\
\hline $19.0 \mathrm{~mm}$ & 1.1 & 1.7 & 1.9 & 2.6 & 0.29 & $<0.01$ & $<0.01$ & 0.67 \\
\hline $8.0 \mathrm{~mm}$ & 8.7 & 10.7 & 7.7 & 9.6 & 0.52 & 0.04 & $<0.01$ & 0.81 \\
\hline $1.18 \mathrm{~mm}$ & 11.4 & 8.9 & 10.4 & 7.5 & 0.61 & $<0.01$ & $<0.01$ & 0.53 \\
\hline $\operatorname{peNDF}_{8.0}{ }^{1}$ & 2.7 & 3.5 & 2.8 & 3.6 & 0.34 & 0.18 & $<0.01$ & 0.86 \\
\hline peNDF $_{1.18}{ }^{1}$ & 5.8 & 6.0 & 6.1 & 6.0 & 0.56 & 0.22 & 0.74 & 0.39 \\
\hline \multicolumn{9}{|c|}{ Digestibility, \% of intake } \\
\hline DM & 59.1 & 58.7 & 66.4 & 63.2 & 1.87 & $<0.01$ & 0.22 & 0.35 \\
\hline $\mathrm{OM}$ & 60.9 & 60.7 & 67.9 & 64.8 & 1.78 & $<0.01$ & 0.24 & 0.29 \\
\hline NDF & 35.0 & 37.3 & 47.4 & 43.8 & 3.71 & $<0.01$ & 0.81 & 0.28 \\
\hline $\mathrm{ADF}$ & 32.7 & 33.0 & 45.0 & 43.7 & 3.86 & $<0.01$ & 0.87 & 0.78 \\
\hline Starch & 88.2 & 88.3 & 92.3 & 91.0 & 1.11 & $<0.01$ & 0.32 & 0.24 \\
\hline $\mathrm{CP}$ & 60.2 & 56.7 & 67.0 & 64.4 & 2.16 & $<0.01$ & 0.08 & 0.80 \\
\hline
\end{tabular}

${ }^{1}$ peNDF $_{8.0}$ and peNDF $_{1.18}=$ physically effective NDF determined as NDF content of TMR multiplied by pef and pef $f_{1.18}$, respectively, where pef $_{8.0}$ and pef $_{1.18}=$ physical effectiveness factor determined as the proportion of particles retained on 2 sieves (Lammers et al., 1996) and 3 sieves (Kononoff et al., 2003), respectively. 
Table 4. Effects of forage-to-concentrate ratio (F:C) and forage particle length (FPL) on intake, duodenal flow, and site and extent of digestion of nutrients in lactating dairy cows $(\mathrm{n}=4)$

\begin{tabular}{|c|c|c|c|c|c|c|c|c|}
\hline \multirow[b]{3}{*}{ Item } & \multicolumn{4}{|c|}{$\mathrm{F}: \mathrm{C}$} & \multirow[b]{3}{*}{$\mathrm{SE}$} & \multirow{2}{*}{\multicolumn{3}{|c|}{$P$-value }} \\
\hline & \multicolumn{2}{|c|}{$35: 65$} & \multicolumn{2}{|c|}{$60: 40$} & & & & \\
\hline & Short & Long & Short & Long & & $\mathrm{F}: \mathrm{C}$ & FPL & $\mathrm{F}: \mathrm{C} \times \mathrm{FPL}$ \\
\hline \multicolumn{9}{|l|}{ Intake, $\mathrm{kg} / \mathrm{d}$} \\
\hline DM & 21.8 & 22.4 & 19.7 & 18.7 & 0.94 & $<0.01$ & 0.77 & 0.18 \\
\hline $\mathrm{OM}$ & 20.1 & 20.7 & 18.1 & 17.0 & 0.86 & $<0.01$ & 0.66 & 0.16 \\
\hline NDF & 5.9 & 6.2 & 5.9 & 5.7 & 0.35 & 0.11 & 0.64 & 0.10 \\
\hline Starch & 6.8 & 7.0 & 4.1 & 3.9 & 0.21 & $<0.01$ & 0.92 & 0.08 \\
\hline \multicolumn{9}{|c|}{ Flow to duodenum, $\mathrm{kg} / \mathrm{d}$} \\
\hline Total OM & 15.3 & 15.0 & 13.3 & 12.4 & 0.75 & $<0.01$ & 0.29 & 0.66 \\
\hline Microbial OM & 3.7 & 3.4 & 2.9 & 3.0 & 0.30 & 0.01 & 0.56 & 0.16 \\
\hline NDF & 3.7 & 3.8 & 3.5 & 3.3 & 0.23 & 0.05 & 0.79 & 0.49 \\
\hline Starch & 2.1 & 2.1 & 1.7 & 1.3 & 0.31 & 0.02 & 0.38 & 0.38 \\
\hline $\mathrm{RDOM},{ }^{1} \mathrm{~kg} / \mathrm{d}$ & 8.6 & 9.2 & 7.7 & 7.6 & 0.46 & 0.05 & 0.67 & 0.64 \\
\hline \multicolumn{9}{|c|}{ Digestibility, ${ }^{2} \%$ of intake } \\
\hline \multicolumn{9}{|c|}{ Rumen } \\
\hline OM (truly) & 42.5 & 44.2 & 42.1 & 45.1 & 2.62 & 0.91 & 0.37 & 0.81 \\
\hline NDF & 36.0 & 37.7 & 44.3 & 39.4 & 3.53 & 0.10 & 0.57 & 0.25 \\
\hline Starch & 69.2 & 69.9 & 59.6 & 62.7 & 3.40 & 0.02 & 0.40 & 0.26 \\
\hline \multicolumn{9}{|l|}{ Intestine } \\
\hline OM & 39.2 & 35.6 & 41.3 & 37.1 & 3.12 & 0.58 & 0.24 & 0.92 \\
\hline $\mathrm{NDF}$ & 1.8 & 3.9 & 3.8 & 3.5 & 1.38 & 0.39 & 0.31 & 0.20 \\
\hline Starch & 21.5 & 20.1 & 33.5 & 29.3 & 3.15 & $<0.01$ & 0.25 & 0.23 \\
\hline \multicolumn{9}{|l|}{ Total } \\
\hline $\mathrm{OM}$ & 63.1 & 63.3 & 67.4 & 64.3 & 2.61 & 0.07 & 0.28 & 0.23 \\
\hline NDF & 37.7 & 41.6 & 48.3 & 42.9 & 3.78 & 0.03 & 0.79 & 0.08 \\
\hline Starch & 90.7 & 90.0 & 93.1 & 92.0 & 1.73 & 0.02 & 0.28 & 0.80 \\
\hline
\end{tabular}

${ }^{1} \mathrm{RDOM}=\mathrm{OM}$ that was truly degraded in the rumen, calculated by correcting for microbial OM.

${ }^{2}$ Digestibility of starch was apparent because microbial glycogen was not accounted for.

interaction between F:C and FPL $(P=0.10)$ occurred for NDF intake, with greater NDF intake of cows fed long FPL when F:C was low without a difference in NDF intake between short and long FPL when F:C was high. Duodenal flows of total OM $(P<0.01)$, microbial OM $(P=0.01)$, NDF $(P=0.05)$, and starch $(P=0.02)$ were less for high $\mathrm{F}$ :C than for low $\mathrm{F}$ :C diets. No effect was observed for FPL or interaction between $\mathrm{F}: \mathrm{C}$ and FPL on the flows of nutrients to the duodenum.

Digestibility (\% of intake) of OM in the rumen did not differ between low and high F:C diets, whereas ruminal truly degraded OM $(\mathbf{R D O M} ; P=0.05)$ and ruminal microbial $\mathrm{OM}$ production $(P<0.01)$ were less with high versus low $\mathrm{F}$ :C diets (Table 4). The digestibility of NDF in the rumen tended $(P=0.10)$ to be greater, but that of starch was lower $(P=0.02)$, with increasing $\mathrm{F}: \mathrm{C}$ ratio. Increased FPL in the diet did not affect ruminal digestibilities of OM, NDF, and starch. Changes in F:C and FPL had no effects on the intestinal digestibilities of $\mathrm{OM}$ and NDF, whereas the intestinal digestibility of starch was less $(P<0.01)$ for the high versus low concentrate diet. In the total digestive tract, increasing $\mathrm{F}$ : $\mathrm{C}$ ratio improved the digestibilities of NDF $(P=0.03)$, starch $(P=0.02)$, and $\mathrm{OM}(P=0.07)$ with no differences in the digest- ibilities of OM, NDF, and starch between short and long FPL.

\section{Nitrogen Metabolism}

Intake of $\mathrm{N}$ was less $(P<0.01)$ in cows fed high versus low $\mathrm{F}$ : $\mathrm{C}$ diets with no effect of FPL and no interaction between F:C and FPL on N intake (Table 5). Duodenal flows of total N $(P<0.01)$, non-ammonia $\mathrm{N}(P<0.01)$, and ruminal undegradable feed $\mathrm{N}(P$ $=0.05)$ were less with high $\mathrm{F}: \mathrm{C}$ than low $\mathrm{F}: \mathrm{C}$ diets. Similarly, the flows of microbial $\mathrm{N}$ to the duodenum decreased with increasing ratio of $\mathrm{F}$ : $\mathrm{C}$ expressed either as grams per day $(P<0.01)$ or as percentage of $\mathrm{N}$ intake $(P=0.09)$. However, efficiency of microbial $\mathrm{N}$ production (g of microbial $\mathrm{N} / \mathrm{kg}$ of $\mathrm{RDOM}$ ) did not differ between low and high F:C diets. Effects of F:C ratio on ruminal degradation and intestinal apparent digestibility of protein were not significant. In contrast, total apparent digestibility of protein was greater $(P=$ 0.02 ) with high versus low F:C. Effects of FPL on flows of $\mathrm{N}$ to the duodenum, microbial protein synthesis, and protein apparent digestibility were not significant. No interaction between F:C and FPL was detected for N metabolism in the rumen and in the intestine. 
Table 5. Effects of forage-to-concentrate ratio (F:C) and forage particle length (FPL) on intake and metabolism of $\mathrm{N}$ in the digestive tract of lactating dairy cows $(\mathrm{n}=4)$

\begin{tabular}{|c|c|c|c|c|c|c|c|c|}
\hline Item & \multicolumn{4}{|c|}{$\mathrm{F}: \mathrm{C}$} & $\mathrm{SE}$ & \multicolumn{3}{|c|}{$P$-value } \\
\hline Intake, $\mathrm{g} / \mathrm{d}$ & 717 & 732 & 630 & 626 & 34.5 & $<0.01$ & 0.79 & 0.66 \\
\hline \multicolumn{9}{|l|}{ Flow to duodenum } \\
\hline Total N, g/d & 715 & 688 & 572 & 570 & 46.9 & $<0.01$ & 0.63 & 0.69 \\
\hline NAN, $\%$ of intake & 97.6 & 92.3 & 88.7 & 89.0 & 6.72 & 0.28 & 0.64 & 0.60 \\
\hline NANMN, $1 \mathrm{~g} / \mathrm{d}$ & 324 & 323 & 286 & 267 & 33.0 & 0.05 & 0.60 & 0.63 \\
\hline NANMN, $\%$ of intake & 44.9 & 44.2 & 45.2 & 42.2 & 3.61 & 0.77 & 0.55 & 0.71 \\
\hline Microbial N, g/d & 373 & 348 & 272 & 287 & 32.2 & $<0.01$ & 0.78 & 0.27 \\
\hline Microbial N, \% of intake & 52.7 & 48.0 & 43.5 & 46.7 & 4.78 & 0.09 & 0.82 & 0.23 \\
\hline Microbial efficiency $^{2}$ & 43.5 & 38.0 & 36.9 & 38.0 & 3.40 & 0.35 & 0.53 & 0.36 \\
\hline \multicolumn{9}{|c|}{ Apparent digestibility, $\%$ of intake } \\
\hline
\end{tabular}

${ }^{1}$ NANMN $=$ nonammonia and nonmicrobial $\mathrm{N}$.

${ }^{2}$ Calculated as g of microbial $\mathrm{N}$ per $\mathrm{kg}$ of ruminally degraded OM.

\section{Ruminal pH and Fermentation}

No interaction was observed between F:C and FPL for ruminal $\mathrm{pH}$ and VFA concentration (Table 6). Mean, minimum, and maximum ruminal $\mathrm{pH}$ increased $(P<$ $0.01)$, but the duration that $\mathrm{pH}<5.8(P<0.01)$ or $\mathrm{pH}$ $<5.5(P=0.06)$ decreased, with increasing $\mathrm{F}$ :C ratio. Increased dietary FPL also increased $(P<0.01)$ mean ruminal $\mathrm{pH}$. Increased $\mathrm{F}$ : $\mathrm{C}$ ratio decreased $(P<0.01)$ total concentration of VFA, increased $(P<0.01)$ the molar proportion of acetate and branched chain VFA, and decreased $(P<0.01)$ the proportion of propionate. As a result, the ratio of acetate to propionate increased $(P<0.01)$. However, increased FPL did not affect the concentration or molar proportions of VFA. Ruminal $\mathrm{NH}_{3}-\mathrm{N}$ concentration was not affected by $\mathrm{F}$ : $\mathrm{C}$ or FPL.

Table 6. Effects of forage-to-concentrate ratio (F:C) and forage particle length (FPL) on ruminal $\mathrm{pH}$ and fermentation characteristics $(\mathrm{n}=8)$

\begin{tabular}{|c|c|c|c|c|c|c|c|c|}
\hline \multirow[b]{3}{*}{ Item } & \multicolumn{4}{|c|}{$\mathrm{F}: \mathrm{C}$} & \multirow[b]{3}{*}{$\mathrm{SE}$} & \multirow{2}{*}{\multicolumn{3}{|c|}{$P$-value }} \\
\hline & \multicolumn{2}{|c|}{$35: 65$} & \multicolumn{2}{|c|}{$60: 40$} & & & & \\
\hline & Short & Long & Short & Long & & $\mathrm{F}: \mathrm{C}$ & FPL & $\mathrm{F}: \mathrm{C} \times \mathrm{FPL}$ \\
\hline \multicolumn{9}{|l|}{$\mathrm{pH}$} \\
\hline Mean & 6.05 & 6.42 & 6.53 & 6.75 & 0.08 & $<0.01$ & $<0.01$ & 0.26 \\
\hline Minimum & 5.43 & 5.62 & 5.86 & 5.94 & 0.17 & $<0.01$ & 0.20 & 0.57 \\
\hline Maximum & 6.50 & 6.58 & 6.74 & 6.84 & 0.08 & $<0.01$ & 0.11 & 0.89 \\
\hline Area $<\mathrm{pH} 5.8, \mathrm{pH} \times \mathrm{h} / \mathrm{d}$ & 1.63 & 0.55 & 0.13 & 0.09 & 0.65 & 0.14 & 0.35 & 0.39 \\
\hline Area $<\mathrm{pH} 5.5, \mathrm{pH} \times \mathrm{h} / \mathrm{d}$ & 0.47 & 0.04 & 0.07 & 0.00 & 0.23 & 0.35 & 0.29 & 0.43 \\
\hline $\mathrm{pH}<5.8, \mathrm{~h} / \mathrm{d}$ & 5.53 & 3.41 & 0.61 & 0.39 & 1.54 & $<0.01$ & 0.44 & 0.34 \\
\hline $\mathrm{pH}<5.5, \mathrm{~h} / \mathrm{d}$ & 0.35 & 0.34 & 0.06 & 0.06 & 0.14 & 0.06 & 0.95 & 0.95 \\
\hline \multicolumn{9}{|l|}{ VFA } \\
\hline Total, $\mathrm{m} M$ & 140.7 & 133.9 & 122.3 & 113.7 & 7.70 & $<0.01$ & 0.17 & 0.87 \\
\hline \multicolumn{9}{|l|}{$\mathrm{Mol} / 100 \mathrm{~mol}$} \\
\hline Acetate $(\mathrm{A})$ & 59.1 & 58.9 & 64.3 & 65.3 & 1.92 & $<0.01$ & 0.75 & 0.65 \\
\hline Propionate $(\mathrm{P})$ & 23.9 & 25.1 & 19.3 & 18.9 & 2.06 & $<0.01$ & 0.79 & 0.57 \\
\hline Butyrate & 13.1 & 12.1 & 11.6 & 11.2 & 0.71 & 0.07 & 0.31 & 0.64 \\
\hline Branched-chain VFA $^{1}$ & 2.0 & 2.1 & 2.9 & 2.9 & 0.18 & $<0.01$ & 0.37 & 0.66 \\
\hline $\mathrm{A}: \mathrm{P}$ ratio & 2.60 & 2.53 & 3.37 & 3.48 & 0.34 & $<0.01$ & 0.92 & 0.63 \\
\hline $\mathrm{NH}_{3}-\mathrm{N}, \mathrm{m} M$ & 10.9 & 10.7 & 10.1 & 10.7 & 1.24 & 0.77 & 0.86 & 0.77 \\
\hline
\end{tabular}

${ }^{1}$ Isobutyrate + isovalerate. 


\section{Milk Production and Composition}

Actual milk and ECM yields were less $(P<0.01)$ for cows fed high F:C (29.0 and $27.5 \mathrm{~kg} / \mathrm{d}$, respectively) than for cows fed low F:C (31.0 and $28.7 \mathrm{~kg} / \mathrm{d}$, respectively; Table 7) diets. However, yield of $4 \%$ FCM only tended $(P=0.10)$ to be less for cows fed high $\mathrm{F}: \mathrm{C}(28.1$ $\mathrm{kg} / \mathrm{d})$ versus low $\mathrm{F}: \mathrm{C}(28.7 \mathrm{~kg} / \mathrm{d})$ diets. Content of milk fat increased $(P<0.01)$, whereas that of milk protein decreased $(P=0.01)$, without altering milk lactose content with increasing $\mathrm{F}: \mathrm{C}$ ratio. As a result, yield of milk fat did not differ, but the yields of milk protein and lactose were decreased $(P<0.01)$ by 11 and $7 \%$, respectively. In addition, milk efficiency was improved by feeding a high $\mathrm{F}: \mathrm{C}$ diet when expressed as ECM $(P=0.02)$ or $4 \%$ FCM $(P=0.01)$ relative to DMI or tended $(P=0.09)$ to improve when expressed as actual milk yield relative to DMI. Milk yield and milk composition were not affected by FPL. A tendency for interaction between $\mathrm{F}: \mathrm{C}$ and FPL on actual milk yield $(P=0.09)$ and lactose yield $(P=0.08)$ occurred with $1.1 \mathrm{~kg} / \mathrm{d}$ less $(P=0.06)$ milk produced or with 0.06 $\mathrm{kg} / \mathrm{d}$ less $(P=0.06)$ lactose produced by cows fed long versus short FPL in a high $\mathrm{F}$ : $\mathrm{C}$ diet without differences between long and short FPL in low F:C diets.

\section{DISCUSSION}

The peNDF system is widely used by the feed industry to formulate diets that meet the needs of dairy cows for the physical attributes of fiber. Although the peNDF system represents a major advancement over NDF in quantifying the physical effectiveness of dietary fiber for cattle, the system has limitations. These include a lack of a standardized method of measuring feed particle length and inconsistent responses in ruminal $\mathrm{pH}$, milk fat, and nutrient digestion to dietary physical effectiveness. In particular, the peNDF concept does not take into consideration differences in diet ruminal degradability, which is a major driver of ruminal $\mathrm{pH}$. White et al. (2017a) proposed replacing the peNDF concept with paNDF, and developed recommendations for minimum forage-NDF and particle length needed to maintain ruminal $\mathrm{pH}$ targets (White et al., 2017b). For the paNDF system, equations were derived by separating particle length from NDF concentration rather than multiplying these variables to obtain peNDF content. The discussion of results from the present study is focused on the effects of dietary $\mathrm{F}$ : $\mathrm{C}$ ratio (i.e., forageNDF content) and FPL in relation to peNDF and paNDF concepts.

Table 7. Effects of forage-to-concentrate ratio (F:C) and forage particle length (FPL) on milk production and composition of lactating dairy cows $(\mathrm{n}=12)$

\begin{tabular}{|c|c|c|c|c|c|c|c|c|}
\hline \multirow[b]{3}{*}{ Item } & \multicolumn{4}{|c|}{$\mathrm{F}: \mathrm{C}$} & \multirow[b]{3}{*}{$\mathrm{SE}$} & \multirow{2}{*}{\multicolumn{3}{|c|}{$P$-value }} \\
\hline & \multicolumn{2}{|c|}{$35: 65$} & \multicolumn{2}{|c|}{$60: 40$} & & & & \\
\hline & Short & Long & Short & Long & & $\mathrm{F}: \mathrm{C}$ & FPL & $\mathrm{F}: \mathrm{C} \times \mathrm{FPL}$ \\
\hline \multicolumn{9}{|c|}{ Milk yield, $\mathrm{kg} / \mathrm{d}$} \\
\hline Actual & 30.8 & 31.1 & 29.5 & 28.4 & 2.53 & $<0.01$ & 0.30 & 0.09 \\
\hline $4 \% \mathrm{FCM}^{1}$ & 28.8 & 28.6 & 28.4 & 27.8 & 2.37 & 0.10 & 0.29 & 0.66 \\
\hline $\mathrm{ECM}^{2}$ & 28.7 & 28.7 & 27.8 & 27.2 & 2.27 & $<0.01$ & 0.41 & 0.47 \\
\hline \multicolumn{9}{|l|}{ Milk fat } \\
\hline$\%$ & 3.63 & 3.50 & 3.78 & 3.89 & 0.266 & $<0.01$ & 0.88 & 0.12 \\
\hline $\mathrm{kg} / \mathrm{d}$ & 1.10 & 1.08 & 1.10 & 1.10 & 0.102 & 0.61 & 0.45 & 0.70 \\
\hline \multicolumn{9}{|l|}{ Milk protein } \\
\hline$\%$ & 3.34 & 3.38 & 3.20 & 3.21 & 0.099 & 0.01 & 0.21 & 0.57 \\
\hline $\mathrm{kg} / \mathrm{d}$ & 1.02 & 1.04 & 0.93 & 0.91 & 0.071 & $<0.01$ & 0.90 & 0.20 \\
\hline \multicolumn{9}{|l|}{ Milk lactose } \\
\hline$\%$ & 4.53 & 4.54 & 4.53 & 4.51 & 0.044 & 0.36 & 0.74 & 0.24 \\
\hline $\mathrm{kg} / \mathrm{d}$ & 1.40 & 1.41 & 1.34 & 1.28 & 0.112 & $<0.01$ & 0.31 & 0.08 \\
\hline \multicolumn{9}{|l|}{ Milk efficiency } \\
\hline Actual/DMI & 1.23 & 1.27 & 1.31 & 1.30 & 0.050 & 0.09 & 0.70 & 0.49 \\
\hline FCM/DMI & 1.16 & 1.17 & 1.26 & 1.28 & 0.049 & 0.01 & 0.71 & 0.81 \\
\hline ECM/DMI & 1.16 & 1.17 & 1.23 & 1.25 & 0.049 & 0.02 & 0.65 & 0.93 \\
\hline $\mathrm{SCC}, \times 10^{5}$ & 1.40 & 1.34 & 1.38 & 1.53 & 0.550 & 0.45 & 0.72 & 0.36 \\
\hline
\end{tabular}

${ }^{1} \mathrm{FCM}$ was calculated as milk yield $(\mathrm{kg} / \mathrm{d}) \times[$ milk fat $(\%) \times 0.15+0.4]$.

${ }^{2} \mathrm{ECM}$ was calculated as milk yield $(\mathrm{kg} / \mathrm{d}) \times\{[0.3887 \times$ milk fat $(\%)]+[0.2356 \times$ milk protein $(\%)]+[0.1653$ $\times$ milk lactose (\%)]\}/3.1338 (Moallem, 2016). 


\section{peNDF Content of Feeds}

Increasing either dietary $\mathrm{FPL}$ or $\mathrm{F}: \mathrm{C}$ ratio resulted in an increase in dietary peNDF ${ }_{8.0}$ content $(+25$ to $+30 \%)$ as expected, whereas dietary peNDF ${ }_{1.18}$ content only increased with increased $\mathrm{F}: \mathrm{C}$ ratio $(+18 \%)$, and not with increasing FPL. Thus, peNDF ${ }_{8.0}$ reflected changes in NDF content (F:C ratio) and particle length, whereas peNDF $_{1.18}$ was insensitive to changes in FPL. Plaizier (2004) reported that about $40 \%$ of dietary pef was contributed by concentrates for diets containing mixed forages (AS, alfalfa hay, and corn silage). In the present study, the contribution of concentrates to pef 8.0 or pef pe.18 $_{1.18}$ varied, respectively: 50 or $60 \%$ for low F:C diets and 20 or $35 \%$ for high F:C diets. Thus, the contribution of concentrates to peNDF can be considerable, especially for low F:C diets. In contrast, FPL did not affect the contribution of concentrates to peNDF. Hence, dietary pef and consequently peNDF is directly affected by F:C ratio and FPL, and indirectly by concentrates when peNDF is increased by increasing forage proportion of the diet.

\section{Intake and Digestibility of Feeds}

A meta-analysis study showed that DMI of dairy cows decreased with increasing forage NDF concentration in the diet (Ferraretto et al., 2013), due to the filling effect of forages. In the present study, the decrease in DMI combined with changes in diet composition with increased $\mathrm{F}: \mathrm{C}$ ratio caused variation in intakes of starch, NDF, and peNDF. Increased dietary peNDF content with increased $\mathrm{F}: \mathrm{C}$ ratio did not increase peNDF intake as much as expected because DMI decreased. The substantial reduction of starch intake $(-40 \%)$ with the high $\mathrm{F}$ : $\mathrm{C}$ diet was due to its lower starch content and lower DMI compared with the low F:C diet.

The lack of FPL effect on DMI is in agreement with studies using lactating cows fed AS-based diets (Clark and Armentano, 2002; Yang and Beauchemin, 2007a; Thomson et al., 2017). In contrast, other studies report decreased DMI with increasing FPL for high-forage diets (100\% barley silage; Soita et al., 2002) or when very long FPL was used (theoretical chop length = $22.3 \mathrm{~mm}$; Kononoff and Heinrichs, 2003), presumably because of increased rumen fill. In addition, it was reported that DMI is sensitive to dietary peNDF content; as peNDF decreases, passage rate and DMI increase (Teimouri Yansari et al., 2004; Zebeli et al., 2008). Conversely, excessive peNDF content may decrease DMI because of the physical limitations of rumen fill (Allen, 2000; Zebeli et al., 2010). Kononoff and Heinrichs (2003) reported DMI of dairy cows fed AS-based diets decreased linearly from $23.4,21.8,20.7$ to $20.1 \mathrm{~kg} / \mathrm{d}$ when dietary peNDF ${ }_{8.0}$ content increased from 10.1, $11.8,13.7$ to $15.2 \%$ of DM. Based on a meta-analysis of the literature, Zebeli et al. (2010) concluded that a dietary peNDF ${ }_{8.0}$ content $\geq 14.9 \%$ of DM lowers DMI. In the present study, increasing dietary peNDF ${ }_{8.0}$ content from 13.4 to $17.5 \%$ by increased FPL in high F:C diets did not negatively affect DMI, unlike the effect of increased F:C ratio. These results indicate that longer chop length of AS did not affect physical fill unlike increased $\mathrm{F}: \mathrm{C}$ ratio, and thus whether peNDF affects DMI may depend upon whether the increase in peNDF is due to an increase in forage proportion or FPL, as well as other factors that limit intake (Allen, 2000).

Increased digestibilities of DM and OM in the total digestive tract resulted from improved digestibilities of $\mathrm{NDF}$, starch, and $\mathrm{CP}$ with increasing $\mathrm{F}$ : $\mathrm{C}$ ratio. The NDF digestibility had the greatest percentage unit increase $(+9.5)$, whereas the increase for CP digestibility $(+7.3)$ was intermediate, and the increase in starch digestibility $(+3.4)$ was lowest. Fiber digestion occurred mainly in the rumen ( $>92 \%$ of digested NDF), which was greater than in a previous study ( $84 \%$; Yang and Beauchemin, 2007a) but less than that reported (98\%) by Moorby et al. (2006). Although Yang and Beauchemin (2007b) and the present study both used AS and similar F:C ratios, the source of grain (barley vs. corn) differed, as did mean ruminal $\mathrm{pH}$ (6.26 vs. 6.44). It appears that when ruminal fiber digestion is compromised due to unfavorable ruminal $\mathrm{pH}$ conditions, there may be partial compensation postruminally. For example, the lower ruminal NDF digestion observed by Yang and Beauchemin (2007a; previous vs. present; 1.96 vs. $2.33 \mathrm{~kg} / \mathrm{d}$ ) was partly compensated for by postruminal digestion ( 0.35 vs. $0.19 \mathrm{~kg} / \mathrm{d}$ ). A recently developed total-tract NDF digestibility model assumes $10 \%$ of NDF digestion occurs in the hindgut of high-producing dairy cows at ad libitum intake (Lopes et al., 2015). The Cornell Net Carbohydrate and Protein System model (Tylutki et al., 2008) assumes $20 \%$ of potentially digestible NDF entering the small intestine is digested.

The lower ruminal starch digestibility of high F:C diets was compensated for by higher intestinal starch digestibility, thus total-tract digestibility of starch was still greater. These results indicate a shift in starch digestion to the lower gut when $\mathrm{F}$ : $\mathrm{C}$ ratio is increased. Similarly, previous studies have reported that low starch digestion in the rumen can be partly or wholly compensated for by intestinal digestion (Yang and Beauchemin, 2007a). A shift of starch digestion from the rumen to the intestine is beneficial for alleviating ruminal acidosis, which may explain the observed improvement in fiber digestion with high $\mathrm{F}$ : $\mathrm{C}$ diets.

The lack of effect of FPL on ruminal and total-tract NDF digestibility contrasts with a previous finding 
that increased FPL of AS in barley-based diets increased ruminal digestibility of NDF and DM (Yang and Beauchemin, 2007a). The discrepancy between the 2 studies for the effect of FPL of AS on NDF digestibility might be due to the differences in ruminal $\mathrm{pH}$ status of cows in the 2 studies (i.e., lower $\mathrm{pH}$ due to use of barley grain by Yang and Beauchemin, 2007b). Manipulating forage FPL appears to be more effective in terms of improving ruminal $\mathrm{pH}$ in barley-based diets compared with corn-based diets, resulting in improved fiber digestion. Ruminal NDF digestibility is typically depressed when ruminal $\mathrm{pH}$ is decreased or feed intake and passage rate are increased due to decreased FPL (Shaver et al., 1988). In the current study, increased FPL of AS only increased mean ruminal $\mathrm{pH}$ and did not affect the duration of $\mathrm{pH}<5.8$ or $\mathrm{pH}<5.5$, which was on average much shorter than in the previous study with barley-based diets ( $\mathrm{pH}<5.8,2.5$ vs. $6.1 \mathrm{~h}$; $\mathrm{pH}$ $<5.5,0.2$ vs. $3.5 \mathrm{~h}$; Yang and Beauchemin, 2007b). The daily duration of $\mathrm{pH}<5.8$ or $\mathrm{pH}<5.5$ is considered more meaningful than mean $\mathrm{pH}$ for affecting fibrolytic microbial activity (Calsamiglia et al., 2002). For this reason, Plaizier et al. (2008) characterized SARA as the duration of ruminal $\mathrm{pH}<5.6$ exceeding 180 min daily.

Lower intake of $\mathrm{N}$ of cows consuming high $\mathrm{F}$ : $\mathrm{C}$ ratio diets was due to their lower DMI. The supply of NAN to the duodenum depends upon the flow of dietary $\mathrm{N}$ (feed + endogenous) and ruminal microbial N. Therefore, the lower flows of NAN with high versus low F:C diets was attributed to the combined decrease in flows of dietary and microbial N. Decreased microbial N production in the rumen with high $\mathrm{F}: \mathrm{C}$ diets is consistent with lower RDOM. Availability of energy and protein are the determinants of ruminal microbial $\mathrm{N}$ production and consequently microbial $\mathrm{N}$ supply is affected by starch intake of cows (Krause et al., 2002). Additionally, the slightly higher sugar (in molasses) and pectin (soluble fiber in beet pulp) content of the low $\mathrm{F}: \mathrm{C}$ diet might have contributed to greater microbial protein synthesis compared with the high $\mathrm{F}$ :C diets (Oba, 2011), whereas the slightly higher fat content of the high $\mathrm{F}$ :C diet would also decrease microbial protein synthesis. Although microbial efficiency ( $\mathrm{g}$ of microbial $\mathrm{N} / \mathrm{kg}$ of RDOM) did not differ, cows fed high F:C diets tended to capture less $\mathrm{N}$ as a proportion of $\mathrm{N}$ intake, suggesting that the protein in high F:C diets was less efficiently used in the rumen. The present findings are in agreement with other studies (Khorasani et al., 2001; Yang and Beauchemin, 2007a) reporting that increased $\mathrm{F}: \mathrm{C}$ ratio decreased the amount of $\mathrm{N}$ supplied to the duodenum and decreased the efficiency of microbial $\mathrm{N}$ captured by dairy cows. Protein digestibility in the intestine can vary with ratio of dietary protein to microbial protein arriving at the duodenum, with feed protein usually being more digestible than microbial protein (Van Soest, 1982). The lack of effect of FPL on $\mathrm{N}$ metabolism in the digestive tract is consistent with its lack of effect on the digestibility of OM, NDF, and starch in the rumen and intestine. The effects of FPL of alfalfa-based diets on $\mathrm{N}$ metabolism in the digestive tract of cattle are inconclusive in the literature (Yang and Beauchemin, 2007a).

\section{Ruminal $\mathrm{pH}$ and Fermentation}

The results demonstrated that increasing $\mathrm{F}$ : $\mathrm{C}$ ratio (i.e., increasing dietary NDF concentration and decreasing starch concentration) is a more effective means of improving ruminal $\mathrm{pH}$ than is increasing dietary FPL. Despite similar intakes of peNDF ${ }_{8.0}$ or peNDF $_{1.18}$, the degree of acidosis (i.e., duration of ruminal $\mathrm{pH}<5.8$ ) was greater in cows fed low versus high $\mathrm{F}$ : $\mathrm{C}$ diets, due to greater starch intake (6.9 vs. $4.0 \mathrm{~kg} / \mathrm{d})$ and higher ruminal starch digestibility (69.6 vs. $61.1 \%$ ) with low F:C diets. These results confirm the limitations of using peNDF for predicting ruminal $\mathrm{pH}$ (White et al., 2017a). Formulating diets on the basis of peNDF without accounting for the degradability of the diet may not prevent SARA when high-grain diets are fed. The lower extent of acidosis for cows fed the low $\mathrm{F}$ : C diet $(\mathrm{pH}$ $<5.8=4.5 \mathrm{~h} / \mathrm{d}$ ) in the present study compared with cows fed barley-based diets $(\mathrm{pH}<5.8=10.8 \mathrm{~h} / \mathrm{d}$; Yang and Beauchemin, 2007b) also confirms the lower risk of SARA for dairy cows fed corn- versus barley-based diets because of the lower digestion rate of corn starch (Zebeli et al., 2012). Kononoff and Heinrichs (2007) recommended that AS should have 10 to $20 \%$ retained on the $19-\mathrm{mm}$ sieve and 45 to $75 \%$ on the 8 -mm sieve, and for TMR, 2 to $8 \%$ on the $19-\mathrm{mm}$ sieve and 30 to $50 \%$ on the $8-\mathrm{mm}$ sieve. These recommendations are based on the assumption that feed particles retained on these sieves promote chewing activity and ruminal mat structure. The particle length distributions of the AS and TMR used in the present study are within the ranges of these recommendations, which may account for the relatively low extent of SARA observed.

The decreased total concentration of VFA, and decreased molar proportion of propionate and increased proportion of acetate and branched chain VFA, with increasing $\mathrm{F}: \mathrm{C}$ ratio were in accordance with decreased RDOM and increased ruminal NDF digestion. Alfalfa silage contains highly soluble and ruminally degradable N (NRC, 2001). Hence, increasing dietary AS inclusion contributes to increased soluble and degradable $\mathrm{N}$ supply in the rumen, and consequently to increased rumen branched-chain VFA molar proportion (Kammes and Allen, 2012). Hassanat et al. (2014) reported that as the proportion of AS in the diet increased, rumi- 
nal branched-chain VFA molar proportion increased. Although the intake of $\mathrm{N}$ was greater with low versus high $\mathrm{F}$ :C diets, the similar ruminal $\mathrm{NH}_{3}-\mathrm{N}$ concentration might be explained by the enhanced supply of fermentable carbohydrates (e.g., starch) in the rumen. Increasing fermentable carbohydrates can decrease ruminal $\mathrm{NH}_{3}-\mathrm{N}$ concentration by reducing the deamination process or enhancing the microbial capture of released AA or released $\mathrm{NH}_{3}-\mathrm{N}$ in the rumen.

\section{Milk Production and Composition}

Responses in milk production primarily reflect changes in $\mathrm{NE}_{\mathrm{L}}$ intake due to changes in DMI or starch intake. In the present study, increasing $\mathrm{F}$ :C ratio from 35:65 to $60: 40$ decreased DMI by 10\%, starch intake by $40 \%$, and RDOM by $14 \%$. However, total-tract digestibility of OM increased by $9 \%$, which partially offset the lower intakes helping to support milk production. Although feeding high F:C diets decreased actual milk yield, milk fat content increased, and thus $4 \%$ FCM yield was only numerically lower for high F:C diets, whereas milk efficiency improved. Increased molar proportion of acetate, the major precursor of de novo synthesis of milk fat, was consistent with the increased concentration of milk fat. Increased acetate production is associated with feeding diets high in forage (NASEM, 2016). In contrast, feeding high versus low F:C decreased RDOM and microbial protein synthesis, accounting for the decrease in concentration of milk protein.

Lack of change in milk production and milk composition with a change in FPL was consistent with the lack of effect on intakes and digestibility of nutrients, ruminal fermentation, and microbial protein synthesis. These results are also consistent with other studies using cows fed AS-based diets (Kononoff and Heinrichs, 2003; Yang and Beauchemin, 2007a; Thomson et al., 2018). The effect of dietary particle length on milk yield or milk components mainly depends on whether it affects DMI (Tafaj et al., 2007; Kmicikewycz and Heinrichs, 2015), which can depend upon the type and quality of forages fed (Caccamo et al., 2014). Lopes et al. (2015) reported that gradually replacing corn silage with AS from 0, 33, 67 to $100 \%$ in dairy cow diets linearly decreased DMI and actual milk yield as well as quadratically changed milk protein and lactose contents. The AS had greater indigestible NDF than did corn silage, a factor that limits DMI and thus milk production (Lopes et al., 2015).

Milk fat content is often used as an indicator of ruminal health and fiber adequacy for dairy cows. Mertens (2000) stated that $20 \%$ peNDF $_{1.18}$ is needed by early to mid-lactation Holstein cows to maintain a milk fat percentage at $3.4 \%$. The present study confirms that recommendation as peNDF 1.18 content of diets ranged from 23 to $28 \%$ of DM and milk fat content from 3.50 to $3.89 \%$ (although method of sieving particles used by Mertens was vertical shaking compared with the PSPS used in the present study). Based on a meta-analysis of the literature in which most studies used the PSPS to determine particle length, Zebeli et al. (2012) suggested that diets containing $<14.9 \%$ peNDF $_{8.0}$ resulted in an imminent risk of acidosis. In the present study, diets with long FPL exceed that recommendation, but diets with short FPL were below the minimum level. Although mean ruminal $\mathrm{pH}$ was decreased when cows were fed diets with peNDF ${ }_{8.0}<14.9 \%$ (i.e., short FPL), milk fat content was not affected, indicating that milk fat content is not always a good indicator of ruminal health and fiber adequacy. Given that intake of peNDF 8 was similar for cows on all diets, the greater milk fat content of cows fed the high F:C was mostly due to changes in rumen fermentation and substrate availability, rather than a change in physical characteristics of the diet per se (although cows fed high F:C diets did consume more long particles). Milk fat content depends on ruminal degradable starch intake in addition to peNDF (Zebeli et al., 2010). Thus, optimum dietary peNDF content depends upon intake of degradable starch from grain because physical fiber affects chewing time and buffering of the rumen, but fermentability affects the production of VFA and consequently milk fat content.

\section{Prediction of Ruminal $\mathrm{pH}$ with peNDF and paNDF Models}

White et al. (2017a) developed equations for peNDF and paNDF to predict ruminal $\mathrm{pH}$. It should be noted that almost all of the studies used by White et al. (2017a) reported mean ruminal pH based on spot sampling, compared with the continuous measurements of $\mathrm{pH}$ used in the present study. The equations developed by White et al. (2017a) included dietary particle length and dietary NDF either combined (peNDF, equations 1 to 4 ) or separately (equations 5 to 8; paNDF). Equations $1,2,5$, and 6 only included dietary variables, whereas equations $3,4,7$, and 8 included dietary and ruminal variables (Table 8). The predictability of ruminal mean $\mathrm{pH}$ varied due to system (peNDF vs. paNDF), prediction equation within system, and experimental diets (F:C ratio and FPL). With peNDF equations, ruminal mean $\mathrm{pH}$ was predicted at a range of 92.6 to $100.2 \%$ of actual using equations 2 and 4 in which sieved material was reported on an as-fed basis. In contrast, equations 1 and 3 that used sieving information on a DM basis failed to accurately predict ruminal $\mathrm{pH}$. Using the 
paNDF models with data from the present 4 experimental diets containing low $\mathrm{F}$ : $\mathrm{C}+$ short, low $\mathrm{F}$ : $\mathrm{C}+$ long, high $\mathrm{F}: \mathrm{C}+$ short, or high $\mathrm{F}: \mathrm{C}+$ long $\mathrm{FPL}$, predicted ruminal $\mathrm{pH}$ was $99.8,93.9,94.9$, or $92.6 \%$ of actual, respectively, with equations 6 or 8; and 103.0, 99.1, 100.9, and $99.6 \%$ of actual with equation 7 . The relatively high agreement for these equations is somewhat surprising given the variability in methodology used to determine mean ruminal $\mathrm{pH}$ ranging from spot sampling to continuous recording. However, paNDF equation 5 failed to predict mean $\mathrm{pH}$. These results indicate no major differences in ruminal mean $\mathrm{pH}$ prediction using either peNDF (using peNDF ${ }_{8.0}$ ) or paNDF systems, when the equations use sieving information expressed on an asfed basis. However, equation 7 of the paNDF system, which considered both dietary and ruminal digestibility variables, showed the best prediction of mean $\mathrm{pH}$, and included sieving on a DM basis. This equation requires inputs of mean particle length, proportion of particles retained on the $8-\mathrm{mm}+19-\mathrm{mm}$ sieves, and contents of forage NDF, CP, starch, ADF:NDF ratio, and rumendegraded NDF content. These results confirm that ruminal $\mathrm{pH}$ prediction can be improved when ruminal degradability of the diet is considered in the prediction equation, although the required inputs and degree of complexity are increased.

Table 8. Measured versus predicted ruminal $\mathrm{pH}$ using models of White et al. $(2017 a)^{1}$

\begin{tabular}{|c|c|c|c|c|c|}
\hline \multirow[b]{3}{*}{ Item } & \multirow{3}{*}{$\begin{array}{l}\text { Model } \\
\text { number }\end{array}$} & \multicolumn{4}{|c|}{ Forage-to-concentrate ratio } \\
\hline & & \multicolumn{2}{|c|}{$35: 65$} & \multicolumn{2}{|c|}{$60: 40$} \\
\hline & & Short $^{2}$ & Long $^{2}$ & Short & Long \\
\hline $\begin{array}{l}\text { Measured } \\
\text { peNDF }\end{array}$ & & 6.05 & 6.42 & 6.53 & 6.75 \\
\hline \multicolumn{6}{|l|}{ Diet } \\
\hline $\mathrm{DM}$ & 1 & $\mathrm{ND}^{3}$ & ND & ND & ND \\
\hline $\mathrm{AF}$ & 2 & 6.04 & 6.03 & 6.20 & 6.25 \\
\hline \multicolumn{6}{|c|}{ Diet + rumen } \\
\hline DM & 3 & ND & ND & ND & ND \\
\hline $\mathrm{AF}$ & 4 & 6.06 & 6.07 & 6.28 & 6.26 \\
\hline \multicolumn{6}{|l|}{ paNDF } \\
\hline \multicolumn{6}{|l|}{ Diet } \\
\hline DM & 5 & ND & ND & ND & ND \\
\hline $\mathrm{AF}$ & 6 & 6.04 & 6.03 & 6.20 & 6.25 \\
\hline \multicolumn{6}{|c|}{ Diet + rumen } \\
\hline DM & 7 & 6.23 & 6.36 & 6.59 & 6.72 \\
\hline $\mathrm{AF}$ & 8 & 6.04 & 6.03 & 6.20 & 6.25 \\
\hline
\end{tabular}

${ }^{1}$ Models of ruminal $\mathrm{pH}$ were derived when dietary particle length was expressed as physically effective NDF (peNDF) or not (physically adjusted NDF; paNDF) multiplied by dietary NDF content and included dietary variables without (diet) or with (diet + rumen) ruminal digestibility when TMR sieved material was reported on an as-fed (AF) or DM basis.

${ }^{2}$ Short or long particle length of alfalfa silage.

${ }^{3} \mathrm{ND}=$ the predicted values were beyond the normal range.

\section{CONCLUSIONS}

Increasing the dietary $\mathrm{F}: \mathrm{C}$ ratio from $35: 65$ to $60: 40$ decreased DMI, amount of RDOM, and ruminal microbial protein synthesis, whereas it improved total-tract digestibility of feed, ruminal $\mathrm{pH}$ status, and milk efficiency. Increasing dietary $\mathrm{F}: \mathrm{C}$ ratio altered the intakes of particles in the various categories (i.e., higher intake of long particles and lower intakes of medium and fine particles), but it did not change the intake of peNDF 8.0 and $\mathrm{peNDF}_{1.18}$. Feeding high F:C diets improved ruminal $\mathrm{pH}$ status and increased fiber digestion due to increased intake of long particles and decreased intake of starch. Increasing dietary FPL increased intake of $\mathrm{peNDF}_{8.0}$, and thus increased mean ruminal $\mathrm{pH}$ for both low and high F:C diets. However, increased dietary FPL showed little beneficial effects on feed digestibility and milk production. Interactions between $\mathrm{F}$ : $\mathrm{C}$ ratio and FPL were few, indicating that increasing chop length of silage had similar effects on response variables for both high and low forage diets. Use of equations derived from the paNDF system improved the predictability of ruminal $\mathrm{pH}$ compared with peNDF-based equations, but predictability varied with diet composition and ruminal degradability of diets.

\section{ACKNOWLEDGMENTS}

This experiment was financially supported by the Dairy of Farmers of Canada (Ottawa, ON) and Agriculture and Agri-Food Canada's Matching Investment Initiative. The authors thank K. Andrews, B. Farr, D. Vedres, and R. Roth (Agriculture and Agri-Food Canada, Lethbridge, AB, Canada) for their assistance in performing sampling and laboratory analyses, and as well as the staff of the Lethbridge Research and Development Centre dairy unit for care of the cows and milk sample collection. The authors have not stated any conflicts of interest.

\section{REFERENCES}

Allen, M. S. 2000. Effects of diet on short-term regulation of feed intake by lactating dairy cattle. J. Dairy Sci. 83:1598-1624. https:// doi.org/10.3168/jds.S0022-0302(00)75030-2.

AOAC International. 2005. Official Methods of Analysis. 16th ed. Association of Official Analytical Chemists, Arlington, VA.

ASAE. 1995. Method of Determining and Expressing Fineness of Feed Material by Sieving. ASAE Standards 1995. ASAE, St. Joseph, MI.

Caccamo, M., J. D. Ferguson, R. F. Veerkamp, I. Schadt, P. Petriglieri, G. Azzaro, A. Pozzebon, and G. Licitra. 2014. Association of total mixed ration particle fractions retained on the Penn State Particle Separator with milk, fat, and protein yield lactation curves at the cow level. J. Dairy Sci. 97:2502-2511. https://doi.org/10.3168/jds .2012-6490.

Calsamiglia, S., A. Ferret, and M. Devant. 2002. Effects of pH and $\mathrm{pH}$ fluctuations on microbial fermentation and nutrient flow from 
a dual-flow continuous culture system. J. Dairy Sci. 85:574-579. https://doi.org/10.3168/jds.S0022-0302(02)74111-8.

Canadian Council on Animal Care. 2009. Guide to the care and use of farm animals in research teaching and testing. E. D. Olfert, B. M. Cross, and A. A. McWilliam, ed. Can. Counc. Anim. Care, Ottawa, Ontario, Canada.

Clark, P. W., and L. E. Armentano. 2002. Influence of particle size on the effectiveness of the fiber in alfalfa silage. J. Dairy Sci. 85:30003007. https://doi.org/10.3168/jds.S0022-0302(02)74385-3.

Ferraretto, L. F., P. M. Crump, and R. D. Shaver. 2013. Effect of cereal grain type and corn grain harvesting and processing methods on intake, digestion and milk production by dairy cows through a meta-analysis. J. Dairy Sci. 96:533-550. https://doi.org/10.3168/ jds.2012-5932.

Hassanat, F., R. Gervais, D. I. Massé, H. V. Petit, and C. Benchaar. 2014. Methane production, nutrient digestion, ruminal fermentation, $\mathrm{N}$ balance, and milk production of cows fed timothy silage- or alfalfa silage-based diets. J. Dairy Sci. 97:6463-6474. https://doi .org/10.3168/jds.2014-8069.

Heinrichs, A. J. 2013. The Penn State Particle Separator. Penn State Extension. Accessed Nov. 15, 2018. http://extension.psu .edu/animals/dairy/nutrition/forages/forage-quality-physical/ separator.

Herrick, K. J., A. R. Hippen, K. F. Kalscheur, J. L. Anderson, S. D. Ranathunga, R. S. Patton, and M. Abdullah. 2012. Lactation performance and digestibility of forages and diets in dairy cows fed a hemicellulose extract. J. Dairy Sci. 95:3342-3353. https://doi.org/ 10.3168/jds.2011-5168.

Kammes, K. L., and M. S. Allen. 2012. Nutrient demand interacts with forage family to affect digestion responses in dairy cows. J. Dairy Sci. 95:3269-3287. https://doi.org/10.3168/jds.2011-5021.

Khorasani, G. R., E. K. Okine, and J. J. Kennelly. 2001. Effects of forage source and amount of concentrate on rumen and intestinal digestion of nutrients in late-lactation cows. J. Dairy Sci. 84:11561165. https://doi.org/10.3168/jds.S0022-0302(01)74576-6.

Kmicikewycz, A. D., and A. J. Heinrichs. 2015. Effect of corn silage particle size and supplemental hay on rumen $\mathrm{pH}$ and feed preference by dairy cows fed high-starch diets. J. Dairy Sci. 98:373-385. https://doi.org/10.3168/jds.2014-8103.

Kononoff, P. J., and A. J. Heinrichs. 2003. The effect of reducing alfalfa haylage particle size on cows in early lactation. J. Dairy Sci. 86:1445-1457. https://doi.org/10.3168/jds.S0022-0302(03)73728 $-\mathrm{X}$.

Kononoff, P. J., and A. J. Heinrichs. 2007. Evaluating particle size of forages and TMRs using the New Penn State Particle Separator. Penn State, College of Agricultural Sciences, Cooperative Extension, DAS 02-42. http://www.researchgate.net/publication/ 292446593

Kononoff, P. J., A. J. Heinrichs, and D. R. Buckmaster. 2003. Modification of Penn State forage and total mixed ration particle separator and the effects of moisture content on its measurements. J. Dairy Sci. 86:1858-1863. https://doi.org/10.3168/jds.S0022 -0302(03)73773-4.

Krause, K. M., D. K. Combs, and K. A. Beauchemin. 2002. Effects of forage particle size and grain fermentability in midlactation cows. I. Milk production and diet digestibility. J. Dairy Sci. 85:19361946. https://doi.org/10.3168/jds.S0022-0302(02)74270-7.

Lammers, B. P., D. R. Buckmaster, and A. J. Heinrichs. 1996. A simple method for the analysis of particle sizes of forage and total mixed rations. J. Dairy Sci. 79:922-928. https://doi.org/10.3168/ jds.S0022-0302(96)76442-1.

Lopes, F., D. E. Cook, and D. K. Combs. 2015. Effects of varying dietary ratios of corn silage to alfalfa silage on digestion of neutral detergent fiber in lactating dairy cows. J. Dairy Sci. 98:6291-6303. https://doi.org/10.3168/jds.2014-8662.

Maulfair, D. D., M. Fustini, and A. J. Heinrichs. 2011. Effect of varying total mixed ration particle size on rumen digesta and fecal particle size and digestibility in lactating dairy cows. J. Dairy Sci. 94:3527-3536. https://doi.org/10.3168/jds.2010-3718.
Mertens, D. R. 1997. Creating a system for meeting the fiber requirements of dairy cows. J. Dairy Sci. 80:1463-1481. https://doi.org/ 10.3168/jds.S0022-0302(97)76075-2.

Mertens, D. R. 2000. Physically effective NDF and its use in dairy rations explored. Feedstuffs 11-14. April 10, 2000.

Moallem, U. 2016. Future consequences of decreasing marginal production efficiency in high-yielding dairy cow. J. Dairy Sci. 99:29862995. https://doi.org/10.3168/jds.2015-10494.

Moorby, J. M., R. J. Dewhurst, R. T. Evans, and J. L. Danelon. 2006. Effects of dairy cow diet forage proportion on duodenal nutrient supply and urinary purine derivative excretion. J. Dairy Sci. 89:3552-3562. https://doi.org/10.3168/jds.S0022-0302(06)72395 -5 .

NASEM (National Academies of Sciences, Engineering, and Medicine). 2016. Nutrient Requirements of Beef Cattle. 8th rev. ed. Natl. Acad. Press, Washington, DC.

NRC. 2001. Nutrient Requirements of Dairy Cattle. 7th rev. ed. Natl Acad. Sci., Washington, DC.

Oba, M. 2011. Review: Effects of feeding sugars on productivity of lactating dairy cows. Can. J. Anim. Sci. 91:37-46. https://doi.org/ 10.4141/CJAS10069

Plaizier, J. C. 2004. Replacing chopped alfalfa hay with alfalfa silage in barley grain and alfalfa-based total mixed rations for lactating dairy cows. J. Dairy Sci. 87:2495-2505. https://doi.org/10.3168/ jds.S0022-0302(04)73374-3.

Plaizier, J. C., D. Krause, G. Gozho, and B. McBride. 2008. Subacute ruminal acidosis in dairy cows: The physiological causes, incidence and consequences. Vet. J. 176:21-31. https://doi.org/10.1016/j .tvjl.2007.12.016.

Rode, L. M., W. Z. Yang, and K. A. Beauchemin. 1999. Fibrolytic enzyme supplements for dairy cows in early lactation. J. Dairy Sci. 82:2121-2126. https://doi.org/10.3168/jds.S0022-0302(99)75455 $-\mathrm{X}$.

Shaver, R. D., A. J. Nytes, L. D. Satter, and N. A. Jorgensen. 1988. Influence of feed intake, forage physical form and forage fiber content on particle size of masticated forage, ruminal digesta, and feces of dairy cows. J. Dairy Sci. 71:1566-1572. https://doi.org/10.3168/ jds.S0022-0302(88)79720-9.

Soita, H. W., D. A. Christensen, J. J. McKinnon, and A. F. Mustafa. 2002. Effects of barley silage of different theoretical cut length on digestion kinetics in ruminants. Can. J. Anim. Sci. 82:207-213. https://doi.org/10.4141/A01-064.

Tafaj, M., Q. Zebeli, Ch. Baes, H. Steingass, and W. Drochner. 2007. A meta-analysis examining effects of particle size of total mixed rations on intake, rumen digestion and milk production in highyielding dairy cows in early lactation. Anim. Feed Sci. Technol. 138:137-161. https://doi.org/10.1016/j.anifeedsci.2007.06.020.

Teimouri Yansari, A., R. Valizadeh, A. Naserian, D. A. Christensen, P. $\mathrm{Yu}$, and F. E. Shahroodi. 2004. Effects of alfalfa particle size and specific gravity on chewing activity, digestibility, and performance of Holstein dairy cows. J. Dairy Sci. 87:3912-3924. https://doi .org/10.3168/jds.S0022-0302(04)73530-4.

Thomson, A. L., D. J. Humphries, L. A. Crompton, and C. K. Reynolds. 2018. The effect of alfalfa (Medicago sativa) silage chop length and inclusion rate within a total mixed ration on the ability of lactating dairy cows to cope with a short-term feed withholding and refeeding challenge. J. Dairy Sci. 101:4180-4192. https://doi .org/10.3168/jds.2017-13926.

Thomson, A. L., D. J. Humphries, K. E. Kliem, M. T. Dittmann, and C. K. Reynolds. 2017. Effects of replacing maize silage with lucerne silage and lucerne silage chop length on rumen function and milk fatty acid composition.. J. Dairy Sci. 100:7127-7138. https:/ /doi.org/10.3168/jds.2017-12914.

Tylutki, T. P., D. G. Fox, V. M. Durbal, L. O. Tedeschi, J. B. Russell, M. E. Van Amburgh, T. R. Overton, L. E. Chase, and A. N. Pell. 2008. Cornell Net Carbohydrate and Protein System: A model for precision feeding of dairy cattle. Anim. Feed Sci. Technol. 143:174202. https://doi.org/10.1016/j.anifeedsci.2007.05.010.

Van Soest, P. J. 1982. Nutritional Ecology of the Ruminant. O\&B Books, Corvallis, OR. 
Van Soest, P. J., J. B. Robertson, and B. A. Lewis. 1991. Methods for dietary fiber, neutral detergent fiber and non starch polysaccharide in relation to animal nutrition. J. Dairy Sci. 74:3583-3597. https://doi.org/10.3168/jds.S0022-0302(91)78551-2.

Wang, H. R., Q. Chen, L. M. Chen, R. F. Ge, M. Z. Wang, L. H. Yu, and J. Zhang. 2017. Effects of dietary physically effective neutral detergent fiber content on the feeding behavior, digestibility, and growth of 8- to 10-month-old Holstein replacement heifers. J. Dairy Sci. 100:1161-1169. https://doi.org/10.3168/jds.2016-10924.

Weatherburn, M. W. 1967. Phenol-hypochlorite reaction for determination of ammonia. Anal. Chem. 39:971-974. https://doi.org/10 $.1021 /$ ac60252a045.

White, R. R., M. B. Hall, J. Firkins, and P. J. Kononoff. 2017a. Physically adjusted neutral detergent fiber system for lactating dairy cow rations. I: Deriving equations that identify factors that influence effectiveness of fiber. J. Dairy Sci. 100:9551-9568. https://doi .org/10.3168/jds.2017-12765.

White, R. R., M. B. Hall, J. Firkins, and P. J. Kononoff. 2017b. Physically adjusted neutral detergent fiber system for lactating dairy cow rations. II: Development of feeding recommendations. J. Dairy Sci. 100:9569-9584. https://doi.org/10.3168/jds.2017-12766.

Woolpert, M. E., H. M. Dann, K. W. Cotanch, C. Melilli, L. E. Chase, R. J. Grant, and D. M. Barbano. 2017. Management practices, physically effective fiber, and ether extract are related to bulk tank milk de novo fatty acid concentration on Holstein dairy farms. J. Dairy Sci. 100:5097-5106. https://doi.org/10.3168/jds.2016-12046.

Yang, W. Z., and K. A. Beauchemin. 2007a. Altering physically effective fiber intake through forage proportion and particle length: Digestion and milk production. J. Dairy Sci. 90:3410-3421. https: //doi.org/10.3168/jds.2006-818.
Yang, W. Z., and K. A. Beauchemin. 2007b. Altering physically effective fiber intake through forage proportion and particle length: Chewing and rumen pH. J. Dairy Sci. 90:2826-2838. https://doi .org/10.3168/jds.2007-0032.

Yang, W. Z., and K. A. Beauchemin. 2009. Increasing physically effective fiber content of dairy cow diets through forage proportion versus forage chop length: Chewing and ruminal $\mathrm{pH}$. J. Dairy Sci. 92:1603-1615. https://doi.org/10.3168/jds.2008-1379.

Zebeli, Q., J. R. Aschenbach, M. Tafaj, J. Boguhn, B. N. Ametaj, and W. Drochner. 2012. Invited review: Role of physically effective fiber and estimation of dietary fiber adequacy in high-producing dairy cattle. J. Dairy Sci. 95:1041-1056. https://doi.org/10.3168/ jds.2011-4421.

Zebeli, Q., D. Mansmann, H. Steingass, and B. N. Ametaj. 2010. Balancing diets for physically effective fibre and ruminally degradable starch: A key to lower the risk of sub-acute rumen acidosis and improve productivity of dairy cattle. Livest. Sci. 127:1-10. https:/ /doi.org/10.1016/j.livsci.2009.09.003.

Zebeli, Q., M. Tafaj, B. Junck, V. Ölschläger, B. N. Ametaj, and W. Drochner. 2008. Evaluation of the response of ruminal fermentation and activities of nonstarch polysaccharide-degrading enzymes to particle length of corn silage in dairy cows. J. Dairy Sci. 91:2388-2398. https://doi.org/10.3168/jds.2007-0810.

\section{ORCIDS}

Chun Li @ https://orcid.org/0000-0002-2436-8366

Karen A. Beauchemin @ https://orcid.org/0000-0002-5070-4554

Wenzhu Yang @ https://orcid.org/0000-0001-9453-924X 